\title{
The influence of consumer personality traits on mobile shopping intention
}

Influence of consumer personality traits

\section{La influencia de los rasgos de personalidad del consumidor en la intención de compra móvil}

\author{
Zaira Camoiras-Rodriguez and Concepción Varela \\ Department of Business Organization and Marketing, \\ University of Santiago de Compostela, Santiago de Compostela, Spain
}

\begin{abstract}
Purpose - This study aims to increase the understanding of the drivers of mobile shopping, by analyzing when and how two personality traits - value consciousness and shopping enjoyment - impact mobile shopping intention through usefulness and ease-of-use perceptions.
\end{abstract}

Design/methodology/approach - To test the conditioned indirect effects, path analysis is used.

Findings - The results indicate that both consumers' value consciousness and shopping enjoyment have a positive indirect effect on mobile shopping intention. However, shopping enjoyment is related only through usefulness, whereas value consciousness is related via both usefulness and ease of use. The results also suggest the need to consider boundary conditions when examining the impact of personality traits.

Practical implications - Mobile retailers need to conduct market segmentation based on users' personalities when trying to increase their customer base.

Originality/value - Despite the relevance of personality traits on individual behavior, studies on the effects that different aspects of personality have on the participation of individuals in mobile commerce are very scarce and show inconsistent results regarding their impact. Thus, this study tries to contribute to the mobile commerce research by analyzing the interplay between two customer characteristics and two mediating variables: ease-of-use and usefulness perceptions.

Keywords Personality traits, M-shopping, Value consciousness, TAM, Shopping enjoyment

Paper type Research paper

(C) Zaira Camoiras-Rodriguez and Concepción Varela. Published in Spanish Journal of Marketing ESIC. Published by Emerald Publishing Limited. This article is published under the Creative Commons Attribution (CC BY 4.0) licence. Anyone may reproduce, distribute, translate and create derivative works of this article (for both commercial and non-commercial purposes), subject to full attribution to the original publication and authors. The full terms of this licence maybe seen at http:// creativecommons.org/licences/by/4.0/legalcode

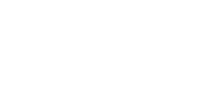




\section{Resumen}

Propósito - Esta investigación busca aumentar la comprensión de los antecedentes de las compras móviles, analizando cuándo y cómo dos rasgos de personalidad - conciencia de valor y disfrute por la compra - afectan a la intención de compra móvil a través de las percepciones de utilidad y facilidad de uso.

Diseño/metodología/enfoque - Para comprobar los efectos indirectos condicionados propuestos se emplea un análisis path.

Hallazgos - Los resultados indican que tanto la conciencia de valor como el disfrute por la compra de los consumidores tienen un efecto indirecto positivo en la intención de compra móvil. Sin embargo, el disfrute por la compra se relaciona sólo a través de la utilidad, mientras que la conciencia de valor se relaciona tanto a través de la utilidad como de la facilidad de uso. Los resultados también sugieren la necesidad de considerar factores moderadores al examinar el impacto de los rasgos de personalidad.

Implicaciones para la gestión - Los minoristas a través del móvil que quieran aumentar su base de clientes necesitan segmentar el mercado en base a la personalidad de los usuarios.

Originalidad/valor - A pesar de la relevancia que tienen los rasgos de personalidad en el comportamiento de los individuos, los estudios sobre los efectos de distintos aspectos de la personalidad sobre la participación de los individuos en el comercio móvil son muy escasos y muestran resultados inconsistentes. Así, este estudio intenta contribuir a la investigación sobre comercio móvil analizando la relación entre dos características del consumidor y dos variables mediadoras: las percepciones de facilidad de uso y utilidad.

Palabras clave Compra móvil, Modelo TAM, Rasgos de personalidad, Conciencia de valor, Disfrute por la compra

Tipo de artículo Trabajo de Investigación

\section{Introduction}

Online sales have been growing nonstop in recent years, and their importance in regards to total retail sales is forecast to continue growing in the coming years (eMarketer, 2019). Mobile commerce, which refers to shopping activities via mobile devices (Ko et al., 2009), comprised over a quarter of total e-commerce in 2019 - more than doubling since 2015, and is expected to be the preferred channel for online shopping within the next five years, in turn driving growth (Business Insider Intelligence, 2019). The reason is a population of mobile service users that surpasses several million nowadays, establishing an important market for mobile service firms (Calvo-Porral and Nieto-Mengotti, 2019). Meanwhile, Grewal et al. (2018), when analyzing the effect of the use of smartphones in stores, found that consumers "spend more time in the store, attend to shelf information more, and divert from their normal path more often, which ultimately increases the amount they purchase" (p. 121). Thus, firms are interested in increasing $\mathrm{m}$-shopping adoption because of its potential contribution to their sales objectives and its positive impact on consumer experiences.

Previous mobile commerce studies have analyzed several factors or drivers to explain its consumer adoption (Groß, 2015a; Hubert et al., 2017; Ko et al., 2009; Liébana-Cabanillas et al., 2017; Sujatha and Sekkizhar, 2019) and have examined different types of mobile commerce innovations (e.g. mobile banking, Shankar et al., 2020; Shareef et al., 2018; mobile shopping apps, McLean et al., 2020; Sarkar et al., 2019; and mobile payment, Liu et al., 2019a, 2019b; Zhang and Mao, 2020), using different theoretical models (e.g. diffusion of innovations theory, theory of reasoned action (TRA), technology acceptance model and unified theory of acceptance and use of technology).

Out of the different theoretical approaches to innovation adoption, the technology acceptance model (TAM; Davis, 1989) is widely accepted (Venkatesh and Davis, 2000) and has been compared favorably to other models, such TRA and theory of planned behavior 
(TPB) (Lu, 2014; Wu et al., 2011). Moreover, it has been previously used to empirically analyze mobile shopping adoption (Aldás-Manzano et al., 2009; Chen et al., 2018; LiébanaCabanillas et al., 2017; San-Martín et al., 2013; Sujatha and Sekkizhar, 2019).

Although previous empirical studies have contributed significantly to the understanding of the factors that drive m-shopping adoption, there are inconsistencies in the obtained results. These inconsistencies may be due to the fact that investigations about mobile shopping acceptance have mainly focused on direct effects without paying attention to indirect effects (Hubert et al., 2017). As a result, mobile shopping adoption continues to attract the attention of practitioners and academics (Sohn and Groß, 2020).

Focusing on the research needs identified above, this study expands TAM and examines how and when two personality traits - shopping enjoyment and value consciousness relate to mobile shopping intention through perceived ease of use and usefulness.

People make purchases for two reasons, hedonic and utilitarian (Jones, 1999). Shopping enjoyment leads individuals to consider the purchase itself as a form of recreation (Kim and Kim, 2008; Wenzel and Benkenstein, 2018), and they obtain psychological rewards from the purchase process itself (Bellenger and Korgaonkar, 1980; Handayani et al., 2018), whereas value consciousness comprises a concern for trying to equilibrate the quality and the price paid for the purchased products and services (Ailawadi et al., 2001). In other words, shopping enjoyment represents an individual's personality trait, linking the pleasure and enjoyable aspects that a consumer derives with the shopping process/activities, regardless of the utilitarian consequences that may be anticipated; whereas value consciousness represents an individual's personality trait related to being rational and functionally driven in the shopping process (Wang et al., 2018). This investigation considers usefulness and ease-of-use perceptions as drivers of the influence of shopping enjoyment and value consciousness on mobile shopping intention. By doing so, it infuses TAM with personality traits to obtain a better understanding of the factors that influence mobile shopping adoption.

Moreover, in technology-mediated environments, consumer characteristics could play a significant role as moderators of relationships when predicting consumer mobile shopping adoption (Yang, 2012). Thus, this study also analyzes the moderating role of both value consciousness and shopping enjoyment on the usefulness perception-mobile shopping adoption and ease-of-use perception mobile shopping adoption relationships. Hence, it develops and empirically tests a moderated mediation model of m-shopping adoption based on the TAM framework that incorporates personality traits.

This investigation makes several relevant contributions to the mobile shopping literature. First, it builds on prior research on mobile shopping by adding previously unanalyzed personality traits - shopping enjoyment and value consciousness - to the still scarce research that relates personality traits to mobile shopping intention (Aldás-Manzano et al., 2009; Mahatanankoon, 2007; Zhou and Lu, 2011). Personality traits have been considered in prior research as key elements to the acceptance of new technologies and to the participation of individuals in online markets (Chang et al., 2013). However, this study's theoretical approach has not been used in previous research examining the determinants of mobile shopping adoption. Mahatanankoon (2007) investigated whether three personality traits (individual playfulness, personal innovativeness and optimum stimulation level) could explain m-commerce intention. Aldás-Manzano et al.'s (2009) study proposed that, together with TAM, three personality variables (innovativeness, affinity and compatibility) are related to mobile shopping intention. Finally, Zhou and Lu (2011) analyzed whether five personality traits (agreeableness, conscientiousness, extroversion, openness to experience and neuroticism) influence user trust and perceived usefulness, which in turn
Influence of consumer personality traits

333 
determine acceptance intention of mobile commerce. None of these studies examines indirect and/or moderation effects of personality. Second, by analyzing the mediating role of usefulness and ease-of-use perceptions in the shopping enjoyment mobile shopping adoption and value-consciousness mobile shopping adoption relationships, it improves understanding of the intervening mechanisms between shopping enjoyment and value consciousness and its outcomes. Third, it also contributes to the literature by examining the moderator role of both value consciousness and shopping enjoyment on the usefulness perception mobile shopping adoption and ease-of-use perception mobile shopping adoption relationships. Accordingly, this study extends prior literature by illustrating how and when personality traits related to shopping motivations result in m-shopping adoption; in addition, it responds to several calls to examine moderating and mediating effects in the TAM (Faqih and Jaradat, 2015; Okazaki and Mendez, 2013).

\section{Literature review and hypotheses}

The basic framework for the proposed model involves the two original variables of TAM: perceived usefulness and ease of use (Chong et al., 2012). Both variables encompass internal perceptions of users (Zhang et al., 2012) and have been widely recognized as strong predictors of individuals' intention to accept or use new technologies (Chi, 2018; Sujatha and Sekkizhar, 2019; Venkatesh et al., 2012). In particular, the m-shopping literature review by Groß (2015b) shows that adoption intention is strongly affected by perceptions of usefulness (performance expectancy) and ease of use (effort expectancy).

Perceived usefulness refers to the degree to which the use of a certain system will improve its users' performance at work (Davis, 1989). In the case of mobile commerce, perceived usefulness covers the degree of utility that the users of this market would assign to the possibility of making purchases through mobile devices.

Perceived ease of use is defined as the degree to which a person considers the use of a particular system to be effortless (Davis, 1989). In mobile commerce, ease of use refers to how easy the individual finds searching for the different products, paying for the purchase or even obtaining after-sales service through mobile devices (Shang et al., 2005).

In addition to these two key mediators, researchers have identified various antecedents of mobile commerce adoption (Groß, 2015a; Hubert et al., 2017; Ko et al., 2009; LiébanaCabanillas et al., 2017; Sujatha and Sekkizhar, 2019). Hubert et al. (2017) have classified these into three groups: mobile benefits, customer characteristics and/or risk perception/costs of using mobile shopping. This study focuses on two customer characteristics, as mobile service users cannot be seen as a uniform group (Calvo-Porral and Otero-Prada, 2020).

Psychological studies have demonstrated that individual behavior is significantly affected by personality traits (Balta et al., 2019; Costa and McCrae, 1992; Woods et al., 2018). Previous research has emphasized the need to incorporate personality traits in technology adoption research to obtain a greater knowledge of their possible effects (Wixom and Todd, 2005). The motive is that personality traits are quite unchanging and not transitory as other kinds of individual characteristics such as moods, attitudes and income (Smith, 2020). However, despite the effect of personality on individual behavior, the existing knowledge about the effects that different traits of personality have on the participation of individuals in online environments, such as mobile commerce, is very scarce (Chang et al., 2013; Groß, 2015b). Consequently, this investigation examines two personality traits: consumer value consciousness, a personality trait tied to a utilitarian approach, and shopping enjoyment, a personality trait linked to a hedonic approach, because research typically explains consumer purchasing or usage behavior as being based on utilitarian and hedonic values (Childers et al., 2001; Moon et al., 2017; Ozturk et al., 2016; Zanjani et al., 2016; Zheng et al., 2019). 
Allport (1937) considered personality as "the dynamic organization within the individual of those psychophysical systems that determine his unique adjustment to his environment" (p. 48). This characterization advocates for the analysis of personality traits, which are defined as "a neuropsychic structure having the capacity to render many stimuli functionally equivalent and to initiate and guide equivalent (meaningfully consistent) forms of adaptive and expressive behavior" (Allport, 1961, p. 347). The trait theory distinguishes individuals based on a comprehensive but limited group of unchanging dispositions that determine an extensive number of important behaviors (Allport, 1937; Funder, 1991; Goldberg, 1993; Wiggins and Pincus, 1992).

Social psychological studies have proposed various multidimensional frameworks for the structure of personality. A widely accepted personality model is the so-called Big Five or five-factor model (Goldberg, 1993; McCrae, 1989). This model exposes an integrative personality approach that covers the wide range of human personality and posits that personality traits can be reduced and categorized under five main factors: agreeableness, conscientiousness, extroversion, openness to experience and neuroticism. However, personality variables have been criticized for having low levels of criterion-related validity, and this can be partly explained by the presumption that all the predictive variance in the personality domain is limited to the variance associated with the Big Five dimensions (Ones et al., 2005). The Big Five dimensions have been considered to be traits that are too general and abstract to explain specific behaviors, such as m-shopping adoption.

On the other hand, social psychology researchers have provided consistent evidence for the hierarchical organization of personality (Soto and John, 2017). Mowen (2000), for example, proposes a four-level hierarchy of personality traits that motivate consumer behavior. According to this hierarchical approach to personality, narrowly defined traits have behavioral connotations and can predict closely matched criteria with greater accuracy than broad traits, like the Big Five dimensions (Ashton et al., 1995; Paunonen and Ashton, 2001). Therefore, instead of using a broad personality model, such as the Big Five, this investigation incorporates narrowly defined personality traits that are expected to be very closely related to mobile shopping. In Mowen's (2000) hierarchy, consumer shopping enjoyment and value consciousness are situational traits, because they reflect durable dispositions to behave in a specific way within a general situational context, in particular, in the context of purchasing products and services (Mowen et al., 2007). As situational traits are closer to behavior than broad traits such as the Big Five, they can be considered proximal personality traits to m-shopping adoption and can be expected to account for more variance in behavior than the more basic dispositions.

The proposed relationship model is presented in Figure 1.

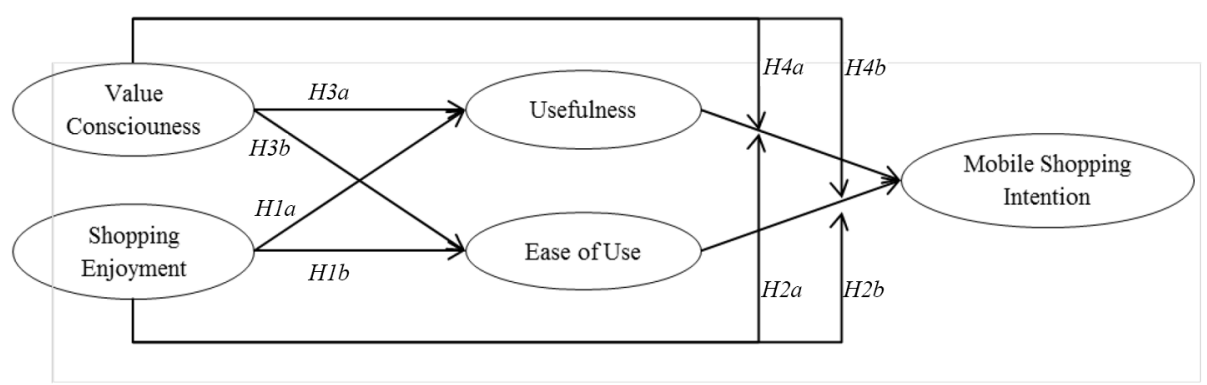

Influence of consumer personality traits

335 


\subsection{Consumer shopping enjoyment}

Shopping enjoyment is considered as one of the main shopping orientations (Brosdahl and Carpenter, 2011) and one of the main determinants of consumer attitude and behavior (Hamari et al., 2016; Seock and Bailey, 2008; So et al., 2018). Martínez-López et al. (2016) found that intrinsic enjoyment is the most significant hedonic motivation in online consumption behavior.

Consumer shopping enjoyment is defined as a personality trait that leads individuals to take on purchases with a more pleasant attitude and with greater pleasure than others (Wong et al., 2012). It represents individuals who enjoy shopping as a leisure time activity and find shopping to be a very enjoyable use of time, regardless of the utilitarian consequences that may be anticipated (Bellenger and Korgaonkar, 1980). In other words, shopping enjoyment refers to the pleasure that an individual experiences when involved in the purchasing process (Beatty and Ferrell, 1998), and consequently, the favorable predisposition of an individual to make purchases of goods or services. To these individuals, making purchases gives them joy and pleasure (Babin et al., 1994; Wenzel and Benkenstein, 2018).

For consumers who enjoy shopping, the purchase itself is a form of recreation, sometimes becoming their favorite leisure time activity (Kim and Kim, 2008). In past research, shopping enjoyment has been identified as one of the antecedents of consumers' search for information (Beatty and Smith, 1987; Hoffman and Novak, 1996). Therefore, consumers who enjoy making purchases will probably spend more time browsing in search of products and services and will also enjoy it more each time. With regard to mobile shopping, this technology offers individuals the possibility of browsing, searching for information and making purchases from a mobile device anywhere and at any time, allowing them to enjoy even more an activity that already brings them pleasure (Paypal, 2018; Rahman et al., 2018; Seock and Bailey, 2008); thus, mobile commerce provides them with an added utility compared to other markets. Thus, we expect that the more the people enjoy shopping, the more usefulness they will get from mobile shopping.

Moreover, consumers who obtain enjoyment from shopping will probably like shopping and not mind having to spend additional time engaging in wide shopping searches (Konus et al., 2008). In this line, Kim et al. (2019) argue that individuals with a high shopping enjoyment orientation tend to enjoy the time invested in extensive searching, regardless of having to change store and (shopping) channel. These kinds of consumers can be considered experienced shoppers, as they will have accumulated experience in the management of the shopping task and process (Riquelme and Román, 2014). Therefore, we maintain that the high levels of knowledge and experience of consumers who enjoy shopping will help them to mobile shop, thus increasing their perception of mobile shopping's ease of use:

H1. Consumer shopping enjoyment has (a) a positive impact on usefulness perception and (b) a positive impact on ease-of-use perception.

Entertainment plays a very important role for individuals who show a high preference for shopping enjoyment (Ailawadi et al., 2001). In this context, previous research reflects that for recreational shoppers, the level of gratification obtained during the process of shopping per se is greater than that obtained with the products and services purchased (Westbrook and Black, 1985). Consequently, in the case of individuals who enjoy making purchases, the effect on their buying behavior of the aspects that help them enjoy these activities or facilitate and complement this pleasant activity will be heightened (Kim and Kim, 2008; Rahman et al., 2018). In other words, for these individuals, it will be more important to enjoy the purchase and, therefore, for the purchase process through the mobile to be easy and 
pleasant; conversely, for these individuals, the usefulness that can be obtained from mobile buying compared to other shopping channels will be less relevant, as they do not buy for utilitarian reasons and, hence will not be so interested in improving their shopping performance:

H2. Consumer shopping enjoyment moderates the positive impact of m-shopping usefulness and ease-of-use perceptions on mobile buying intention so that the greater the consumer's shopping enjoyment (a) the lower the impact of usefulness perception and (b) the greater the impact of ease-of-use perception.

\subsection{Consumer value consciousness}

In online shopping, according to Martínez-López et al. (2016), economy is one of the most significant utilitarian motivations. The 2017 Global Online Consumer Report (KPMG International, 2017) shows that two of the main reasons to shop online instead of in stores are price-related: ability to compare prices and online sale/better prices.

Value consciousness refers to a concern for paying a reduced price for a given level of quality (Ailawadi et al., 2001). In other words, it is a personality trait that represents the level to which individuals show a predisposition to try to equilibrate the quality and the price paid for their purchased products and services (Lichtenstein et al., 1990). Value-conscious individuals' underlying motive is to be - and show significant third parties that they are "smart shoppers" by obtaining the best value for money (Delgado-Ballester et al., 2014). Consequently, consumers with higher value consciousness are more rational and functionally driven (Wang et al., 2018).

Most consumers, when the product requirements are satisfied, favor the option with the lowest price. Nevertheless, high value-conscious consumers are more concerned with the benefit-cost ratio than other consumers, which causes them to search harder for products and services to maximize the value obtained (Lichtenstein et al., 1990). Hence, valueconscious consumers worry about both low prices and product quality (Ismail, 2017; Riorini, 2018) and are inclined to rely on information as the basis of their intention to make more accurate decisions and secure the best value for money (Pillai and Kumar, 2012). Consequently, value-conscious consumers spend more time collecting relevant information about products and services, and they are also likely to check and compare the prices of different brands to obtain the best possible value for money (Itani et al., 2019). Given that mobile shopping offers individuals the possibility of browsing, searching for information and making purchases from a mobile device wherever and whenever they want, it provides an added benefit compared to other markets, especially for those individuals with high value consciousness, who are more concerned about getting additional product information.

Likewise, it can also be expected that high value-conscious consumers, who are used to actively seeking relevant product information, will be experienced shoppers who have accumulated additional shopping experience. Therefore, as reasoned with shopping enjoyment, we argue that the higher experience and knowledge of value-conscious consumers will help them to mobile shop, thus making them perceive mobile shopping as easier to use:

H3. Consumer value consciousness has (a) a positive impact on m-shopping usefulness perception, and (b) a positive impact on m-shopping ease-of-use perception.

Individuals with high levels of value consciousness tend to try to maximize the value obtained in all their transactions (Dutta and Biswas, 2005), not only from an economic point 
of view but also from a utilitarian point of view. High value-conscious consumers have a high concern for utility, seeking to obtain it not only in the products acquired but also through the channels used (Lichtenstein et al., 1990). At the same time, compared to other consumers, high value-conscious consumers will make extra effort to look for products that provide the best value (Lichtenstein et al., 1990); in other words, they are used to putting effort and work into, among other things, reviewing and comparing products' prices and quality (Mowen, 2000). Thus, for these consumers, ease of use will not be such a determining factor when making a decision, as they are used to working to improve the purchasing process, while usefulness will be even more important, as utility governs their shopping behavior in every sense:

H4. Consumer value consciousness moderates the positive impact of m-shopping usefulness and ease-of-use perceptions on mobile buying intention so that the greater the consumer's value consciousness (a) the greater the impact of usefulness perception and (b) the lower the impact of ease-of-use perception.

\section{Methodology}

\subsection{Sample}

The proposed hypotheses were studied in a convenience sample of individuals who have mobile devices with Internet access. Data were collected through personal interviews using a structured survey. The number of valid surveys obtained was 208 .

\subsection{Measurement scales}

To measure the constructs considered in this study, we used five-point Likert scales adapted from previous investigations to the specifics of $m$-shopping. The constructs comprised in the TAM, i.e. mobile shopping intention, usefulness and ease of use, were measured using three, four and four items, respectively, extracted from Venkatesh et al. (2012). Regarding the personality trait variables, value consciousness was measured using seven items extracted from Lichtenstein et al. (1990), and shopping enjoyment was measured using four items extracted from Seock and Bailey (2008). Appendices 1 and 2 show the scales' measures and descriptive statistics.

\subsection{Psychographic properties of the scales}

To ensure correct usage of the scales, a measurement model of all the constructs was subjected to confirmatory factor analysis using EQS. The results of the measurement model are included in Appendix 1. The overall robust fit indices are indicative of a good fit of the model to the data. Regarding reliability, all variables have a Cronbach's $\alpha$ greater than 0.7 , a composite reliability (CR) greater than 0.6 and an average variance extracted (AVE) greater than 0.5. In addition, convergent validity is supported (all lambda parameters are greater than 0.5 and are statistically significant) as well as discriminant validity (correlations among all variables show confidence intervals that do not include the unit value, and their squared value does not exceed the AVE of the factors involved), as shown in Appendix 2.

\subsection{Analytical strategy}

Together, the proposed relationships imply a moderated mediation process (Bauer et al., 2006; Edwards and Lambert, 2007). A moderated mediation process entails that the indirect effect of the independent variable on the dependent variable, via the mediator, differs in strength across low and high levels of the moderator (Edwards and Lambert, 2007). In other 
words, for moderated mediation to exist, there must be different conditional indirect relationships between consumer shopping enjoyment and value consciousness and mobile shopping intention via usefulness and ease of use across low and high levels of the moderators. To assess the proposed moderated mediation process, we carried out path analysis using Stata (Table 1), following the steps outlined by Preacher et al. (2007). Path analysis offers the possibility to model the relationships among multiple independent and dependent constructs simultaneously, showing a more complete picture of the whole model (Bullock et al., 1994) while eliminating the complexity of using latent variables in a moderated mediation model. Thus, we substituted the constructs by the average score of the indicators, grouping them in a single measure. Moreover, to avoid problems when interpreting some coefficients, given the measurement scales of some of the considered variables (which do not include the value zero), the variables involved in the interaction terms were centered on the mean.

\section{Results}

The results reported in Table 1 reveal that perceived usefulness and ease of use have a positive effect on mobile shopping intention. The findings also show that shopping enjoyment has a positive impact on perceived usefulness so that higher levels of shopping enjoyment relate to greater perceived usefulness with the use of mobile shopping; thus, supporting H1a. However, there is no significant relationship between shopping enjoyment and perceived ease of use; therefore, $H 1 \mathrm{~b}$ is not supported. Regarding the impact of value consciousness, the results reveal that it has a positive effect on both perceived usefulness and ease of use. $H 3 a$ and $H 3 b$ are, therefore, supported, so higher levels of value
Influence of consumer personality traits

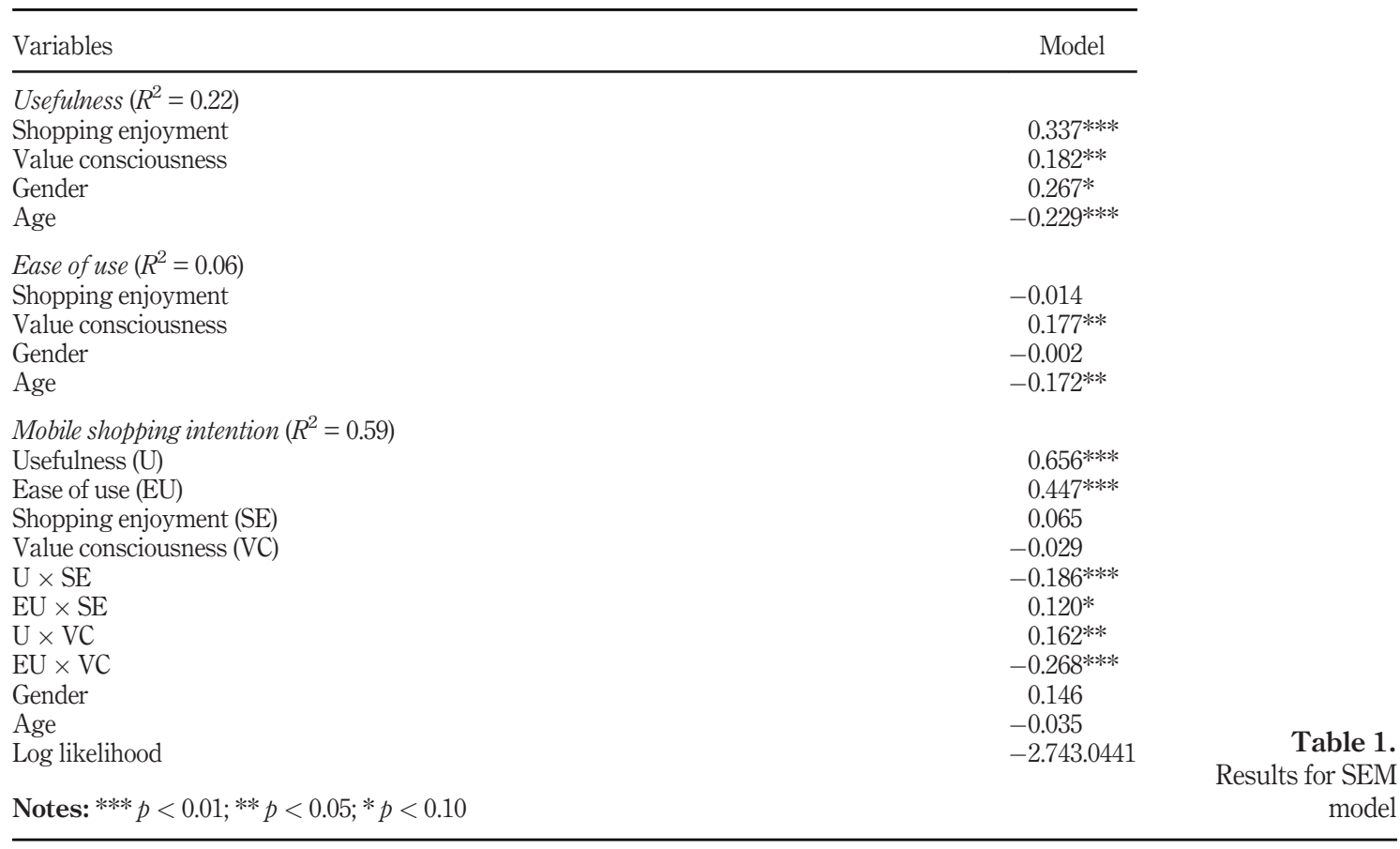


SJME

24,3

\section{0}

Figure 2.

Relationship between usefulness and mobile shopping intention at high and low levels of shopping enjoyment consciousness are associated with greater perceptions of ease in the use and usefulness of mobile shopping.

Furthermore, the findings also show a significant negative moderating effect of shopping enjoyment on the relationship between usefulness and mobile shopping intention, as well as a significant positive moderating effect of shopping enjoyment on the relationship between ease of use and mobile shopping intention. This indicates a stronger positive relationship between ease of use and mobile shopping intention, and a weaker positive relationship between usefulness and mobile shopping intention, the greater the customer's shopping enjoyment. Hence, $H 2 a$ and $H 2 b$ are both supported. Figures 2 and 3 display these interactions using the process proposed by Dawson (2014).

As regards to the moderator role of value consciousness, the results show a significant negative interaction effect between value consciousness and ease of use and a significant

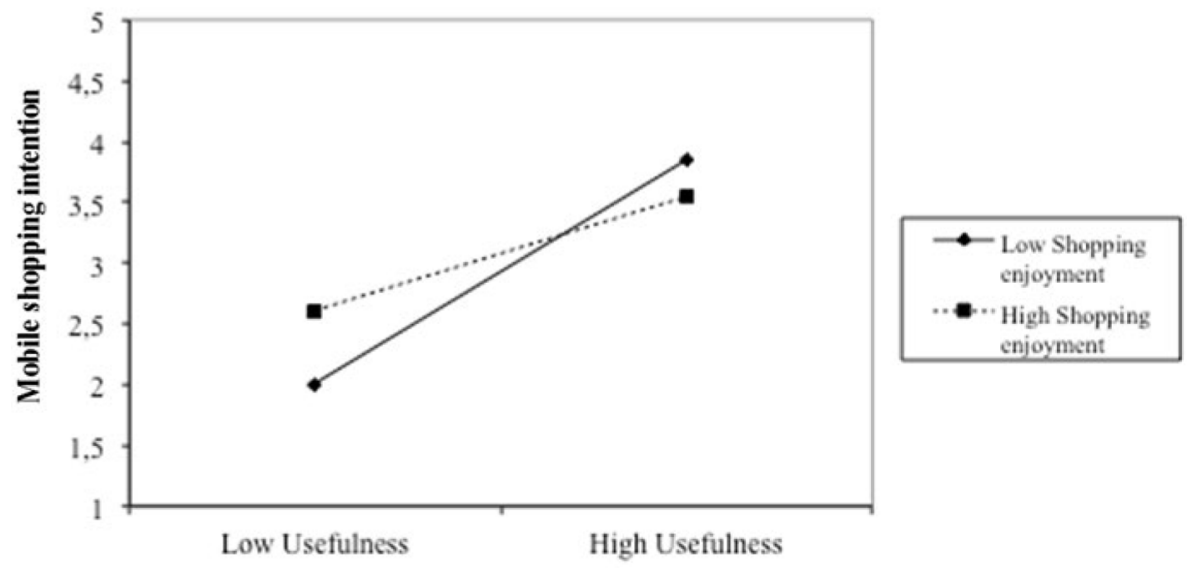

Notes: High $=1 \mathrm{SD}$ above the mean; Low $=1 \mathrm{SD}$ below the mean

Notes: High $=1$ SD above the mean; Low $=1$ SD below the mean

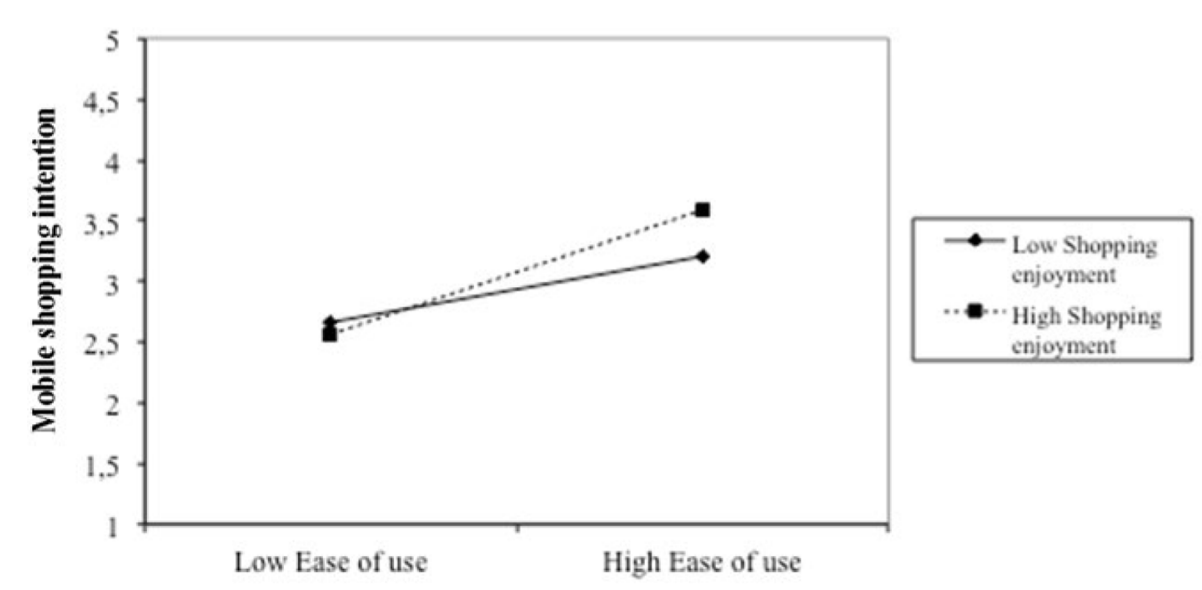

Figure 3.

Relationship between ease of use and mobile shopping intention at high and low levels of shopping enjoyment 
positive interaction effect between value consciousness and usefulness on mobile shopping intention, supporting $H 4 a$ and $H 4 b$. Thus, higher levels of value consciousness will increase the positive effect of usefulness on mobile shopping intention while reducing the positive effect of ease of use. Figures 4 and 5 show these interactions following the process used by Dawson (2014).

However, to establish a moderated mediation process, the strength of the mediation must vary across different levels of the moderator. Therefore, to further analyze the moderated mediation, we used bootstrapped 95\% confidence intervals (CIs; resulting from 5,000 replications) following Preacher et al. (2007). As the results do not support the assumption that shopping enjoyment is related to ease of use, the significance of the indirect relationship between shopping enjoyment and mobile shopping intention was only computed via usefulness for consumers with low/moderate/high levels of shopping enjoyment and low/

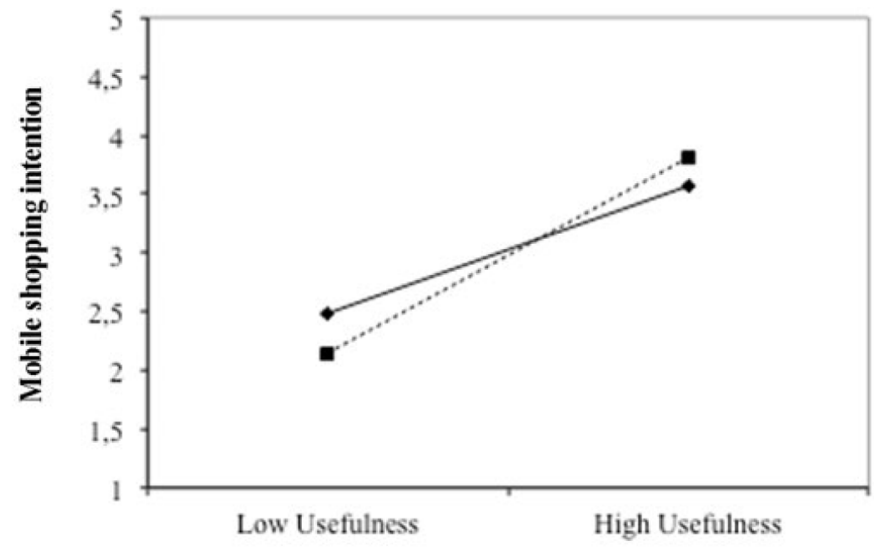

Notes: High $=1 \mathrm{SD}$ above the mean; Low $=1 \mathrm{SD}$ below the mean

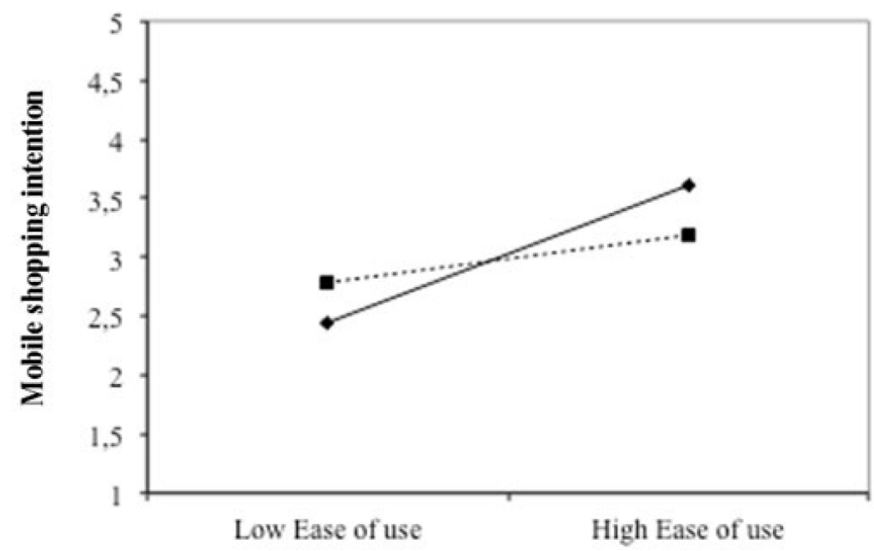

Notes: High $=1 \mathrm{SD}$ above the mean; Low $=1 \mathrm{SD}$ below the mean
Influence of consumer personality traits

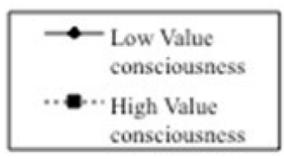

Figure 4.

Relationship between usefulness and mobile shopping intention at high and low levels of value consciousness

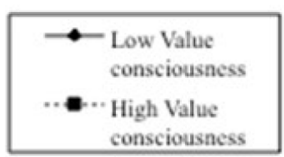

Figure 5.

Relationship between ease of use and mobile shopping intention at high and low levels of value consciousness 
moderate/high levels of value consciousness. On the other hand, the significance of the indirect relationships between value consciousness and mobile shopping intention was calculated via usefulness and ease of use for consumers with low/moderate/high levels of shopping enjoyment and low/moderate/high levels of value consciousness.

The findings (Table 2) show that both shopping enjoyment and value consciousness are positively and indirectly related to mobile shopping intention via usefulness for all levels of shopping enjoyment and value consciousness. In particular, the results reveal that these positive indirect links through usefulness are greater the lower the customers' shopping enjoyment and the greater their value consciousness. Similarly, the findings show that value consciousness is positively and indirectly associated with mobile shopping intention via ease of use for all levels of customers' shopping enjoyment and value consciousness. Moreover, the results also reveal that this positive indirect relationship between value consciousness and mobile shopping intention via ease of use is greater the greater the customer's shopping enjoyment or lower the value consciousness.

\section{Discussion}

As mobile commerce is expected to be the preferred channel for online shopping within the next five years and a major contributor to sales growth (Business Insider Intelligence, 2019), the focus of this study was to explore $\mathrm{m}$-shopping intention from a personality perspective. Specifically, this research tried to understand how and when two situational personality traits - consumer shopping enjoyment and value consciousness - affect m-shopping intention, by expanding the TAM. By doing so, this study contributes to theory and research in a number of important ways.

First, as personality is a crucial factor to explain individual attitudes and behavior (Hirsh and Dolderman, 2007), and more specifically consumer behavior (Bosnjak et al., 2007), this study extends research by adding to the still scarce literature that relates personality traits to mobile shopping intention (Groß, 2015b). The results obtained in the empirical analyses supported the proposed model and showed the relevant role that shopping enjoyment and value consciousness play in the mobile shopping context. These findings are in line with previous research that explains consumer shopping behavior using an utilitarian and hedonic approach (Demoulin and Willems, 2019; Liu et al., 2019a, 2019b; Singh, 2019; Vieira et al., 2018).

Second, as there is a need to address individual differences as predictors of perceived ease of use and usefulness (Li, 2013), this study contributes to research on the TAM by analyzing the foregoing impact of personality traits. In particular, the findings supported the proposed positive relationships between consumer shopping enjoyment and usefulness, as well as between consumer value consciousness and both usefulness and ease of use. Customers who enjoy shopping as well as those who are value conscious spend more time shopping than other customers. Although they do it for different reasons, both types of customers like to browse longer than other customers do. As mobile shopping offers the possibility of browsing, searching for information and making purchases from a mobile device anywhere and anytime, it gives them added utility compared to other markets. At the same time, high value-conscious customers seem to accumulate more experience and knowledge with regards to the shopping process than low value-conscious customers, which helps them to mobile shop and increases their perception of its ease of use. Conversely, the proposed positive relationship between consumer shopping enjoyment and ease of use was not significant. This may be because, in the case of consumers who enjoy purchases, there can be two opposite effects that cancel the impact of shopping enjoyment on the ease-of-use perception. On the one hand, it can be expected that their greater experience with the 


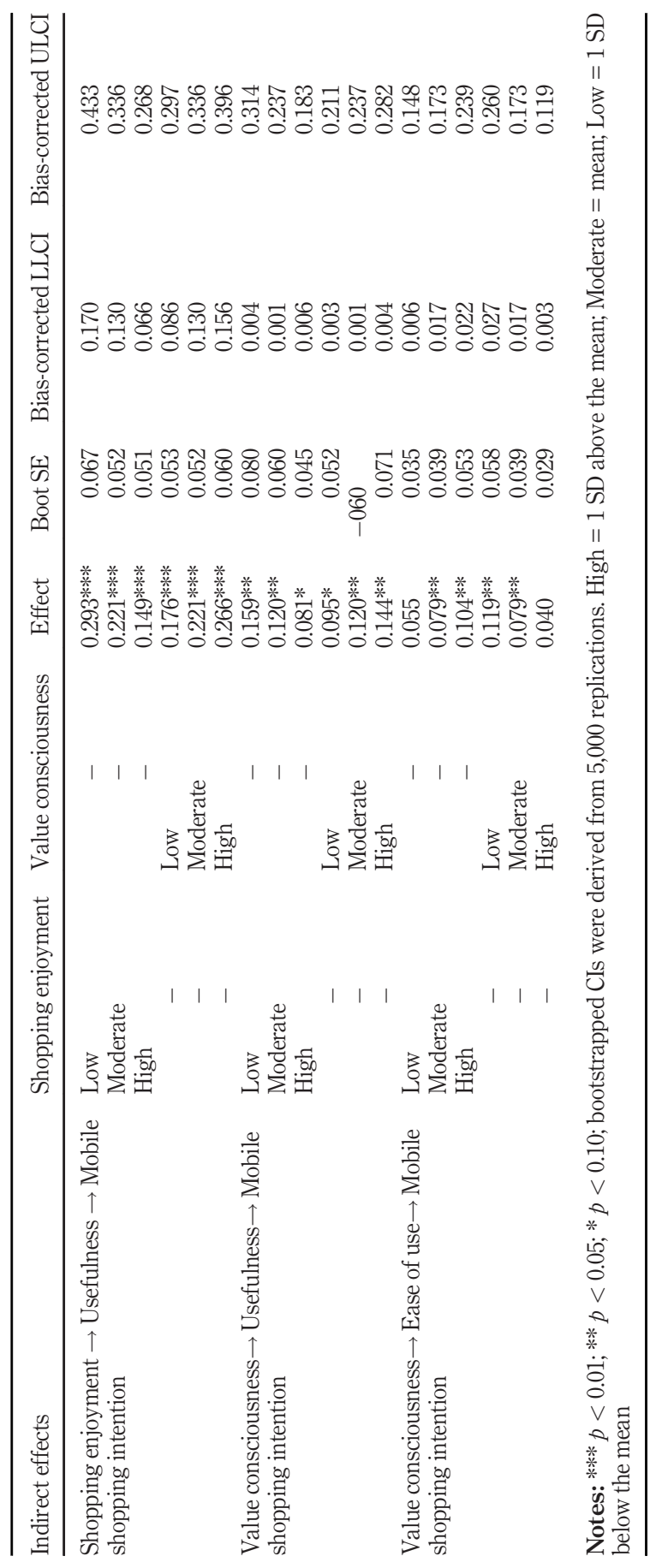

Influence of consumer personality traits

343

Table 2.

Test of indirect effects on $\mathrm{m}$ shopping intention 
shopping process will have a positive effect on their ease-of-use perception, in line with what happened with the value-conscious customers. On the other hand, previous research has demonstrated a positive relationship between consumers' shopping enjoyment and materialism (Burroughs and Rindfleisch, 2002; Mokhtarian et al., 2006; Riquelme and Román, 2014) and a negative relationship between consumers' materialism and their selfesteem (Mick, 1996). Hence, if customers who enjoy shopping do so because of their materialism, and materialistic customers tend to have low self-esteem, it could be expected that the low self-esteem of those customers who enjoy shopping will make them perceive mobile shopping as a more difficult process.

Regarding the influence of the usefulness and perceived ease of use on m-shopping intention, our results supported the multiple arguments throughout the literature about the important positive effects of these constructs on the adoption of technology, specifically in a mobile shopping context (Sujatha and Sekkizhar, 2019). However, they additionally supported the conclusion that personality traits can hinder or enhance the positive effects of the usefulness and ease-of-use perceptions. In particular, our results showed, in line with what was proposed, that consumer shopping enjoyment increases the relevance of ease-ofuse perceptions and reduces the importance of usefulness perceptions. In other words, customers who enjoy shopping will look for a shopping process that is easy and pleasant and will not worry so much about its utility, as improving their performance in the purchase process is not essential. On the other hand, consumer value consciousness has the opposite effect, i.e. high value-conscious customers, who strive to improve the purchasing process and whose behavior is governed by the usefulness of things or channels, attach less importance to ease-of-use perceptions and more to usefulness perceptions. Therefore, our investigation extends knowledge on TAM, as it analyzes the moderating effect of previously unexplored personality traits, which relate to the shopping context, on the TAM main relationships, in line with recent investigations (Devaraj et al., 2008; Lu et al., 2019; RamírezCorrea et al., 2019).

Finally, as previous investigations have mainly focused on direct drivers of mobile shopping adoption (Hubert et al., 2017), this study extends research on mobile shopping by analyzing conditional indirect effects. Our results indicated that consumer shopping enjoyment is positively and indirectly related to mobile shopping intention through the extent to which customers find mobile shopping useful, and that this indirect relationship is dependent on their level of shopping enjoyment and value consciousness. Specifically, the indirect relationship between consumer shopping enjoyment and mobile shopping intention is greater, the greater the value consciousness or the lower the shopping enjoyment. Moreover, our findings showed that consumer value consciousness is positively and indirectly related to mobile shopping intention via the extent to which customers find mobile shopping useful or easy to use. Particularly, the indirect relationship between consumer value consciousness and mobile shopping intention via perceived usefulness is greater when customers show less shopping enjoyment or more value consciousness. Conversely, the indirect relationship between consumer value consciousness and mobile shopping intention via perceived ease of use is greater when customers show less value consciousness or more shopping enjoyment. Therefore, the present study contributes to both the mobile shopping and the TAM literature by illustrating under which conditions the indirect effects of personality traits on mobile shopping intention via TAM exist.

From a managerial perspective, our study offers several implications for mobile retailers. First, our findings suggest that consumers' perception of higher accessibility, simplicity of use and browsing possibilities of product information offered in the mobile channel lead to intention to use this shopping channel. Therefore, mobile retailers may place special 
emphasis on their mobile platform's capability to provide expert and useful information to potential buyers in a friendly and simple way.

Second, the diverse effects of consumer shopping enjoyment and value consciousness on mobile shopping adoption suggest that mobile retailers need to conduct market segmentation based on users' personalities. Value-conscious customers or customers who enjoy shopping seem to be prone to try mobile shopping. Thus, mobile retailers should target their efforts on these users to broaden their user base. For example, marketing programs such as discount information, new product trials and other deal-prone activities should be supplied to appeal to customers with value consciousness. On the other hand, when trying to appeal to customers who enjoy shopping, mobile retailers may have to find ways to enable these customers to shop with friends or socialize with others, e.g. with "bring a friend with you" promotions or special events, or may need to consider the employment of "new" and "novel" activities based on the self, wrapped up in a shopping experience.

Another key practical implication that can be derived from our results is that mobile retailers should take into consideration which type of customers they are trying to address when planning their communication efforts. Mobile retailers should furnish information with a bigger focus on mobile usefulness when addressing value conscious customers, whereas they should give greater consideration to mobile ease of use when addressing customers who enjoy shopping.

Finally, it is necessary to present the limitations of these empirical results. The main limitation is that all the constructs used are self-reported. Although self-reports were an appropriate way of obtaining information for this research and they have been used in similar studies, the influence of common method bias in the obtained results cannot be totally excluded (Podsakoff $e$ t al., 2003). Another limitation of the study is the cross-sectional nature of the data, i.e. the study was carried out at a specific moment in time and, as a result, causality can only be inferred from these data. Consequently, it would be necessary to carry out a longitudinal study to reaffirm the causal relationships. The convenience sampling used in this investigation is another limitation of the study. Future research should use other sampling methods to ensure the generalizability of results. Researchers have several other possibilities regarding future research. First, future studies might duplicate the proposed model in a different shopping context. Second, they may analyze the impact of these personality traits across the different stages of shopping. Third, they could study the impact of customer shopping enjoyment and value consciousness alongside the Big Five personality traits on mobile shopping intention. Fourth, and last, they may also consider investigating the effects of shopping enjoyment and value consciousness in a cross-cultural context, to explore whether its related behaviors change through different cultures, in line with $\mathrm{Ng}$ (2013).

\section{References}

Ailawadi, K.L., Neslin, S.A. and Gedenk, K. (2001), "Pursuing the value-conscious consumer: store brands versus national brand promotions", Journal of Marketing, Vol. 65 No. 1, pp. 71-89.

Aldás-Manzano, J., Ruiz-Mafé, C. and Sanz-Blas, S. (2009), "Exploring individual personality factors as drivers of M-shopping acceptance”, Industrial Management and Data Systems, Vol. 109 No. 6, pp. 739-757.

Allport, G.W. (1937), Personality: A Psychological Interpretation, Holt, Rinehart and Winston, New York, NY.

Allport, G.W. (1961), Pattern and Growth in Personality, Holt, Rinehart and Winston, New York, NY. 
Ashton, M.C., Jackson, D.N., Paunonen, S.V., Helmes, E. and Rothstein, M.G. (1995), "The criterion validity of broad factor scales versus specific facet scales", Journal of Research in Personality, Vol. 29 No. 4, pp. 432-442.

Babin, B.J., Darden, W.R. and Griffin, M. (1994), "Work and/or fun: measuring hedonic and utilitarian shopping value", Journal of Consumer Research, Vol. 20 No. 4, pp. 644-656.

Balta, S., Jonason, P., Denes, A., Emirtekin, E., Tosuntaş, ŞB., Kircaburun, K. and Griffiths, M.D. (2019), "Dark personality traits and problematic smartphone use: the mediating role of fearful attachment", Personality and Individual Differences, Vol. 149, pp. 214-219.

Bauer, D.J., Preacher, K.J. and Gil, K.M. (2006), "Conceptualizing and testing random indirect effects and moderated mediation in multilevel models: new procedures and recommendations", Psychological Methods, Vol. 11 No. 2, pp. 142-163.

Beatty, S.E. and Ferrell, M.E. (1998), "Impulse buying: modeling its precursors", Journal of Retailing, Vol. 74 No. 2, pp. 169-191.

Beatty, S.E. and Smith, S.M. (1987), "External search effort: an investigation across several product categories", Journal of Consumer Research, Vol. 14 No. 1, pp. 83-95.

Bellenger, D.N. and Korgaonkar, P.K. (1980), "Profiling the recreational shopper", Journal of Retailing, Vol. 56, pp. 71-91.

Bosnjak, M., Bratko, D., Galesic, M. and Tuten, T. (2007), "Consumer personality and individual differences: revitalizing a temporarily abandoned field”, Journal of Business Research, Vol. 60 No. 6, pp. 587-589.

Brosdahl, D.J. and Carpenter, J.M. (2011), "Shopping orientations of US males: a generational cohort comparison", Journal of Retailing and Consumer Services, Vol. 18 No. 6, pp. 548-554.

Bullock, H.E., Harlow, L.L. and Mulaik, S.A. (1994), "Causation issues in structural equation modeling research”, Structural Equation Modeling: A Multidisciplinary Journal, Vol. 1 No. 3, pp. 253-267.

Burroughs, J.E. and Rindfleisch, A. (2002), "Materialism and well-being: a conflicting values perspective", Journal of Consumer Research, Vol. 29 No. 3, pp. 348-370.

Business Insider Intelligence (2019), "Rise of m-commerce: mobile ecommerce shopping stats and trends in 2020", available at: www.businessinsider.com/mobile-commerce-shopping-trendsstats? IR=T (accessed 30 May 2020).

Calvo-Porral, C. and Nieto-Mengotti, M. (2019), "The moderating influence of involvement with ICTs in mobile services", Spanish Journal of Marketing - ESIC, Vol. 23 No. 1, pp. 25-43.

Calvo-Porral, C. and Otero-Prada, L. (2020), "A profile of mobile service users in a mature market: from 'uninvolved pragmatics' to 'potential switchers", Spanish Joumal of Marketing - ESIC, accepted for publication.

Chang, A., Hsieh, S.H. and Lin, F. (2013), "Personality traits that lead members of online brand communities to participate in information sending and receiving", International Journal of Electronic Commerce, Vol. 17 No. 3, pp. 37-62.

Chen, Y.M., Hsu, T.H. and Lu, Y.J. (2018), "Impact of flow on mobile shopping intention”, Journal of Retailing and Consumer Services, Vol. 41, pp. 281-287.

Chi, T. (2018), "Understanding Chinese consumer adoption of apparel mobile commerce: an extended TAM approach", Journal of Retailing and Consumer Services, Vol. 44, pp. 274-284.

Childers, T.L., Carr, C.L., Peck, J. and Carson, S. (2001), "Hedonic and utilitarian motivations for online retail shopping behavior", Journal of Retailing, Vol. 77 No. 4, pp. 511-535.

Chong, A.Y.L., Chan, F.T. and Ooi, K.B. (2012), "Predicting consumer decisions to adopt mobile commerce: cross country empirical examination between China and Malaysia", Decision Support Systems, Vol. 53 No. 1, pp. 34-43.

Costa, P.T. and McCrae, R.R. (1992), Revised NEO Personality Inventory (NEO-PI-R) and NEO FiveFactor Inventory (NEO-FFI) Professional Manual, Psychological Assessment Resources, Odessa, FL. 
Davis, F.D. (1989), "Perceived usefulness, perceived ease of use, and user acceptance of information technology”, MIS Quarterly, Vol. 13 No. 3, pp. 319-340.

Dawson, J.F. (2014), "Moderation in management research: what, why, when, and how", Journal of Business and Psychology, Vol. 29 No. 1, pp. 1-19.

Delgado-Ballester, E., Hernandez-Espallardo, M. and Rodriguez-Orejuela, A. (2014), "Store image influences in consumers' perceptions of store brands: the moderating role of value consciousness", European Journal of Marketing, Vol. 48 Nos 9/10, pp. 1850-1869.

Demoulin, N. and Willems, K. (2019), "Servicescape irritants and customer satisfaction: the moderating

Influence of consumer personality traits role of shopping motives and involvement", Journal of Business Research, Vol. 104, pp. 295-306.

Devaraj, S., Easley, R.F. and Crant, J.M. (2008), "How does personality matter? Relating the five-factor model to technology acceptance and use", Information Systems Research, Vol. 19 No. 1, pp. 93-105.

Dutta, S. and Biswas, A. (2005), "Effects of low price guarantees on consumer post-purchase search intention: the moderating roles of value consciousness and penalty level", Journal of Retailing, Vol. 81 No. 4, pp. 283-291.

Edwards, J.R. and Lambert, L.S. (2007), "Methods for integrating moderation and mediation: a general analytical framework using moderated path analysis", Psychological Methods, Vol. 12 No. 1, pp. 1-22.

eMarketer (2019), "Global ecommerce 2019. Ecommerce continues strong gains amid global economic uncertainty", available at: www.emarketer.com/content/global-ecommerce-2019 (accessed 21 May 2020).

Faqih, K.M. and Jaradat, M.I.R.M. (2015), "Assessing the moderating effect of gender differences and individualism-collectivism at individual-level on the adoption of mobile commerce technology: TAM3 perspective", Journal of Retailing and Consumer Services, Vol. 22, pp. 37-52.

Funder, D.C. (1991), "Global traits: a neo-Allportian approach to personality”, Psychological Science, Vol. 2 No. 1, pp. 31-39.

Goldberg, L.R. (1993), “The structure of phenotypic personality traits”, American Psychologist, Vol. 48 No. 1, pp. 26-34.

Grewal, D., Ahlbom, C.P., Beitelspacher, L., Noble, S.M. and Nordfält, J. (2018), "In-store mobile phone use and customer shopping behavior: evidence from the field", Journal of Marketing, Vol. 82 No. 4, pp. 102-126.

Groß, M. (2015a), "Exploring the acceptance of technology for mobile shopping: an empirical investigation among smartphone users", The International Review of Retail, Distribution and Consumer Research, Vol. 25 No. 3, pp. 215-235.

Groß, M. (2015b), "Mobile shopping: a classification framework and literature review", International Journal of Retail and Distribution Management, Vol. 43 No. 3, pp. 221-241.

Hamari, J., Sjöklint, M. and Ukkonen, A. (2016), "The sharing economy: why people participate in collaborative consumption", Journal of the Association for Information Science and Technology, Vol. 67 No. 9, pp. 2047-2059.

Handayani, W., Anshori, M., Usman, I. and Mudjanarko, S. (2018), "Why are you happy with impulse buying? Evidence from Indonesia”, Management Science Letters, Vol. 8 No. 5, pp. 283-292.

Hirsh, J.B. and Dolderman, D. (2007), "Personality predictors of consumerism and environmentalism: a preliminary study", Personality and Individual Differences, Vol. 43 No. 6, pp. 1583-1593.

Hoffman, D.L. and Novak, T.P. (1996), "Marketing in hypermedia computer-mediated environments: conceptual foundations", Journal of Marketing, Vol. 60 No. 3, pp. 50-68.

Hubert, M., Blut, M., Brock, C., Backhaus, C. and Eberhardt, T. (2017), “Acceptance of smartphonebased mobile shopping: mobile benefits, customer characteristics, perceived risks, and the impact of application context", Psychology and Marketing, Vol. 34 No. 2, pp. 175-194. 
Ismail, A.R. (2017), "The influence of perceived social media marketing activities on brand loyalty: the mediation effect of brand and value consciousness", Asia Pacific Journal of Marketing and Logistics, Vol. 29 No. 1, pp. 129-144.

Itani, O.S., Kassar, A.N. and Loureiro, S.M.C. (2019), "Value get, value give: the relationships among perceived value, relationship quality, customer engagement, and value consciousness", International Journal of Hospitality Management, Vol. 80, pp. 78-90.

Jones, M.A. (1999), "Entertaining shopping experiences: an exploratory investigation", Journal of Retailing and Consumer Services, Vol. 6 No. 3, pp. 129-139.

Kim, E., Libaque-Saenz, C.F. and Park, M.C. (2019), "Understanding shopping routes of offline purchasers: selection of search-channels (online vs. offline) and search-platforms (mobile vs. PC) based on product types”, Service Business, Vol. 13 No. 2, pp. 305-338.

Kim, H.Y. and Kim, Y.K. (2008), "Shopping enjoyment and store shopping modes: the moderating influence of chronic time pressure", Journal of Retailing and Consumer Services, Vol. 15 No. 5, pp. 410-419.

Ko, E., Kim, E.Y. and Lee, E.K. (2009), "Modeling consumer adoption of mobile shopping for fashion products in Korea", Psychology and Marketing, Vol. 26 No. 7, pp. 669-687.

Konus, U., Verhoef, P.C. and Neslin, S.A. (2008), "Multichannel shopper segments and their covariates", Journal of Retailing, Vol. 84 No. 4, pp. 398-413.

KPMG International (2017), "The truth about online consumers. 2017 global online consumer report", available at: https://assets.kpmg/content/dam/kpmg/xx/pdf/2017/01/the-truth-about-onlineconsumers.pdf (accessed 24 May 2020).

Li, C.F. (2013), "The revised technology acceptance model and the impact of individual differences in assessing internet banking use in Taiwan", International Journal of Business and Information, Vol. 8 No. 1, pp. 96-119.

Lichtenstein, D.R., Netemeyer, R.G. and Burton, S. (1990), "Distinguishing coupon proneness from value consciousness: an acquisition-transaction utility theory perspective", Journal of Marketing, Vol. 54 No. 3, pp. 54-67.

Liébana-Cabanillas, F., Marinković, V. and Kalinić, Z. (2017), "A SEM-neural network approach for predicting antecedents of m-commerce acceptance", International Journal of Information Management, Vol. 37 No. 2, pp. 14-24.

Liu, F., Lim, E.T., Li, H., Tan, C.W. and Cyr, D. (2019a), "Disentangling utilitarian and hedonic consumption behavior in online shopping: an expectation disconfirmation perspective", Information and Management, Vol. 57 No. 3, p. 103199.

Liu, Z., Ben, S. and Zhang, R. (2019b), "Factors affecting consumers' mobile payment behavior: a metaanalysis", Electronic Commerce Research, Vol. 19 No. 3, pp. 575-601.

Lu, J. (2014), "Are personal innovativeness and social influence critical to continue with mobile commerce?”, Internet Research, Vol. 24 No. 2, pp. 134-159.

Lu, Y., Papagiannidis, S. and Alamanos, E. (2019), "Exploring the emotional antecedents and outcomes of technology acceptance", Computers in Human Behavior, Vol. 90, pp. 153-169.

McCrae, R.R. (1989), "Why I advocate the five-factor model: joint factor analyses of the NEO-PI with other instruments", Personality Psychology, Springer, New York, NY, pp. 237-245.

McLean, G., Osei-Frimpong, K., Al-Nabhani, K. and Marriott, H. (2020), "Examining consumer attitudes towards retailers' m-commerce mobile applications - an initial adoption vs. continuous use perspective", Journal of Business Research, Vol. 106, pp. 139-157.

Mahatanankoon, P. (2007), "The effects of personality traits and optimum stimulation level on textmessaging activities and m-commerce intention", International Journal of Electronic Commerce, Vol. 12 No. 1, pp. 7-30.

Martínez-López, F.J., Pla-García, C., Gázquez-Abad, J.C. and Rodríguez-Ardura, I. (2016), "Hedonic motivations in online consumption behaviour", International Journal of Business Environment, Vol. 8 No. 2, pp. 121-151. 
Mick, D.G. (1996), “Are studies of dark side variables confounded by socially desirable responding? The case of materialism", Journal of Consumer Research, Vol. 23 No. 2, pp. 106-119.

Mokhtarian, P.L., Ory, D.T. and Cao, X. (2006), "Shopping-related attitudes: a factor and cluster analysis of Northern California shoppers", Environment and Planning B: Planning and Design, Vol. 36 No. 2, pp. 204-228.

Moon, M.A., Khalid, M.J., Awan, H.M., Attiq, S., Rasool, H. and Kiran, M. (2017), “Consumer's perceptions of website's utilitarian and hedonic attributes and online purchase intentions: a cognitive - affective attitude approach", Spanish Journal of Marketing - Esic, Vol. 21 No. 2, pp. 73-88.

Mowen, J.C. (2000), The 3M Model of Motivation and Personality: Theory and Empirical Applications to Consumer Behavior, Springer Science and Business Media.

Mowen, J.C., Park, S. and Zablah, A. (2007), "Toward a theory of motivation and personality with application to word-of-mouth communications", Journal of Business Research, Vol. 60 No. 6, pp. 590-596.

$\mathrm{Ng}$, C.S.P. (2013), "Intention to purchase on social commerce websites across cultures: a crossregional study", Information and Management, Vol. 50 No. 8, pp. 609-620.

Okazaki, S. and Mendez, F. (2013), "Exploring convenience in mobile commerce: moderating effects of gender", Computers in Human Behavior, Vol. 29 No. 3, pp. 1234-1242.

Ones, D.S., Viswesvaran, C. and Dilchert, S. (2005), "Personality at work: raising awareness and correcting misconceptions", Human Performance, Vol. 18 No. 4, pp. 389-404.

Ozturk, A.B., Nusair, K., Okumus, F. and Hua, N. (2016), "The role of utilitarian and hedonic values on users' continued usage intention in a mobile hotel booking environment", International Journal of Hospitality Management, Vol. 57, pp. 106-115.

Paunonen, S.V. and Ashton, M.C. (2001), "Big five factors and facets and the prediction of behavior", Journal of Personality and Social Psychology, Vol. 81 No. 3, pp. 524-539.

Paypal (2018), "Paypal mcommerce index: 2018 trend report", available at: www.paypalobjects.com/ digitalassets/c/website/marketing/apac/au/mcommerce-index/paypal-trendreport-2018.pdf (accessed 10 June 2020).

Pillai, K.G. and Kumar, V. (2012), "Differential effects of value consciousness and coupon proneness on consumers' persuasion knowledge of pricing tactics", Journal of Retailing, Vol. 88 No. 1, pp. 20-33.

Podsakoff, P.M., MacKenzie, S.B., Lee, J.Y. and Podsakoff, N.P. (2003), "Common method biases in behavioral research: a critical review of the literature and recommended remedies", Journal of Applied Psychology, Vol. 88 No. 5, pp. 879-903.

Preacher, K.J., Rucker, D.D. and Hayes, A.F. (2007), "Addressing moderated mediation hypotheses: theory, methods, and prescriptions", Multivariate Behavioral Research, Vol. 42 No. 1, pp. 185-227.

Rahman, M.A., Islam, M.A., Esha, B.H., Sultana, N. and Chakravorty, S. (2018), "Consumer buying behavior towards online shopping: an empirical study on Dhaka city, Bangladesh", Cogent Business and Management, Vol. 5 No. 1, p. 1514940.

Ramírez-Correa, P., Grandón, E.E., Alfaro-Pérez, J. and Painén-Aravena, G. (2019), "Personality types as moderators of the acceptance of information technologies in organizations: a multi", Sustainability", , Vol. 11 No. 14, pp. 1-15.

Riorini, S.V. (2018), "Social media marketing toward perceptual consciousness and its impact on online purchasing intention", European Research Studies Journal, Vol. 21 No. 1, pp. 402-416.

Riquelme, I.P. and Román, S. (2014), "The influence of consumers' cognitive and psychographic traits on perceived deception: a comparison between online and offline retailing contexts", Journal of Business Ethics, Vol. 119 No. 3, pp. 405-422.

San-Martín, S., López-Catalán, B. and Ramón-Jerónimo, M.A. (2013), "Mobile shoppers: types, drivers, and impediments", Journal of Organizational Computing and Electronic Commerce, Vol. 23 No. 4, pp. 350-371.

Influence of consumer personality traits 
SJME

24,3

Sarkar, S., Khare, A. and Sadachar, A. (2019), "Influence of consumer decision-making styles on use of mobile shopping applications", Benchmarking: An International Journal, Vol. 27 No. 1, pp. 1-20.

Seock, Y.K. and Bailey, L.R. (2008), "The influence of college students' shopping orientations and gender differences on online information searches and purchase behaviours", International Journal of Consumer Studies, Vol. 32 No. 2, pp. 113-121.

Shang, R.A., Chen, Y.C. and Shen, L. (2005), "Extrinsic versus intrinsic motivations for consumers to shop on-line", Information and Management, Vol. 42 No. 3, pp. 401-413.

Shankar, A., Jebarajakirthy, C. and Ashaduzzaman, M. (2020), "How do electronic word of mouth practices contribute to mobile banking adoption?”, Journal of Retailing and Consumer Services, Vol. 52, p. 101920.

Shareef, M.A., Baabdullah, A., Dutta, S., Kumar, V. and Dwivedi, Y.K. (2018), "Consumer adoption of mobile banking services: an empirical examination of factors according to adoption stages", Journal of Retailing and Consumer Services, Vol. 43, pp. 54-67.

Singh, R. (2019), "Why do online grocery shoppers switch or stay? An exploratory analysis of consumers' response to online grocery shopping experience", International Journal of Retail and Distribution Management, Vol. 47 No. 12, pp. 1300-1317.

Smith, T.A. (2020), "The role of customer personality in satisfaction, attitude-to-brand and loyalty in mobile services", Spanish Journal of Marketing - ESIC, accepted for publication.

Sohn, S. and Groß, M. (2020), "Understanding the inhibitors to consumer mobile purchasing intentions", Journal of Retailing and Consumer Services, Vol. 55, p. 102129.

Soto, C.J. and John, O.P. (2017), "The next big five inventory (BFI-2): developing and assessing a hierarchical model with 15 facets to enhance bandwidth, fidelity, and predictive power", Journal of Personality and Social Psychology, Vol. 113 No. 1, pp. 117-143.

Sujatha, R. and Sekkizhar, J. (2019), "Determinants of m-commerce adoption in India using technology acceptance model infused with innovation diffusion theory", Journal of Management Research, Vol. 19 No. 3, pp. 193-204.

Venkatesh, V. and Davis, F.D. (2000), "A theoretical extension of the technology acceptance model: four longitudinal field studies", Management Science, Vol. 46 No. 2, pp. 186-204.

Venkatesh, V., Thong, J.Y. and Xu, X. (2012), “Consumer acceptance and use of information technology: extending the unified theory of acceptance and use of technology", MIS Quarterly, Vol. 36 No. 1, pp. 157-178.

Vieira, V., Santini, F.O. and Araujo, C.F. (2018), "A meta-analytic review of hedonic and utilitarian shopping values”, Journal of Consumer Marketing, Vol. 35 No. 4, pp. 426-437.

Wang, W., He, H., Sahadev, S. and Song, W. (2018), “UK consumers' perceived risk of buying products from emerging economies: a moderated mediation model”, Journal of Consumer Behaviour, Vol. 17 No. 3, pp. 326-339.

Wenzel, S. and Benkenstein, M. (2018), "Together always better? The impact of shopping companions and shopping motivation on adolescents' shopping experience", Journal of Retailing and Consumer Services, Vol. 44, pp. 118-126.

Westbrook, R.A. and Black, W.C. (1985), "A motivation-based shopper typology”, Journal of Retailing, Vol. 61, pp. 78-103.

Wiggins, J.S. and Pincus, A.L. (1992), "Personality: structure and assessment", Annual Review of Psychology, Vol. 43 No. 1, pp. 473-504.

Wixom, B.H. and Todd, P.A. (2005), "A theoretical integration of user satisfaction and technology acceptance", Information Systems Research, Vol. 16 No. 1, pp. 85-102.

Wong, Y.T., Osman, S., Jamaluddin, A. and Yin-Fah, B.C. (2012), "Shopping motives, store attributes and shopping enjoyment among Malaysian youth", Journal of Retailing and Consumer Services, Vol. 19 No. 2, pp. 240-248. 
Woods, S., Mustafa, M., Anderson, N.R. and Sayer, B. (2018), "Innovative work behavior and personality traits: examining the moderating effects of organizational tenure", Journal of Managerial Psychology, Vol. 33 No. 1, pp. 29-42.

Wu, L., Li, J.Y. and Fu, C.Y. (2011), "The adoption of mobile healthcare by hospital's professionals: an integrative perspective", Decision Support Systems, Vol. 51 No. 3, pp. 587-596.

Influence of consumer personality traits

Yang, K. (2012), "Consumer technology traits in determining mobile shopping adoption: an application of the extended theory of planned behavior", Journal of Retailing and Consumer Services, Vol. 19 No. 5, pp. 484-491.

Zanjani, S.H., Milne, G.R. and Miller, E.G. (2016), "Procrastinators' online experience and purchase behavior", Journal of the Academy of Marketing Science, Vol. 44 No. 5, pp. 568-585.

Zhang, J. and Mao, E. (2020), "Cash, credit, or phone? An empirical study on the adoption of mobile payments in the United States", Psychology and Marketing, Vol. 37 No. 1, pp. 87-98.

Zhang, L., Zhu, J. and Liu, Q. (2012), "A meta-analysis of mobile commerce adoption and the moderating effect of culture”, Computers in Human Behavior, Vol. 28 No. 5, pp. 1902-1911.

Zheng, X., Men, J., Yang, F. and Gong, X. (2019), "Understanding impulse buying in mobile commerce: an investigation into hedonic and utilitarian browsing", International Journal of Information Management, Vol. 48, pp. 151-160.

Zhou, T. and Lu, Y. (2011), "The effects of personality traits on user acceptance of mobile commerce", International Journal of Human-Computer Interaction, Vol. 27 No. 6, pp. 545-561. 
MOBILE SHOPPING INTENTION: $(\alpha=0.975 ; \mathrm{IFC}=0.976 ; \mathrm{AVE}=0.932)$

I intend to use mobile devices to carry out shopping operations in the loading $(\lambda)^{*}$

future

I will use mobile devices to shop products/services

I plan to use mobile devices to shop in the future

USEFULNESS: $(\alpha=0.885 ; \mathrm{IFC}=0.671 ; \mathrm{AVE}=0.890)$.

I would find mobile shopping useful in my daily life

Using mobile shopping would increase my chances of achieving things

that are important to me

Using mobile shopping would help me accomplish things more quickly

Using mobile shopping would increase my productivity

EASE OF USE: $(\alpha=0.906 ; \mathrm{IFC}=0.908 ; \mathrm{AVE}=0.711)$.

Learning how to use mobile shopping would be easy for me

Carrying out shopping operations through a mobile device would be clear

and understandable

I find mobile shopping would be easy to use

It would be easy for me to become skillful at mobile shopping

VALUE CONSCIOUSNESS: $(\alpha=0.868 ; \mathrm{IFC}=0.876 ; \mathrm{AVE}=0.507)$.

I am very concerned about low prices, but I am equally concerned about

When grocery shopping, I compare the prices of different brands to be sure

I get the best value for the money

When purchasing a product, I always try to maximize the quality I get for the money I spend

When I buy products, I like to be sure that I am getting my money's worth

I generally shop around for lower prices on products, but they still must

When I shop, I usually compare the "Price per ounce" information for brands I normally buy

I always check prices at the grocery store to be sure I get the best value for the money I spend

SHOPPING ENJOYMENT: $(\alpha=0.878 ; \mathrm{IFC}=0.887 ; \mathrm{AVE}=0.668)$.

I enjoy shopping for clothes

Table A1.

Measurement scales used and properties 


\begin{tabular}{llllll}
\hline & 1 & 2 & 3 & 4 & 5 \\
\hline 1. Mobile shopping intention & $\mathbf{0 . 9 3 2}$ & & & & \\
2. Usefulness & 0.637 & $\mathbf{0 . 6 7 1}$ & & & \\
3. Ease of use & 0.362 & 0.269 & $\mathbf{0 . 7 1 1}$ & & \\
4. Value consciousness & 0.027 & 0.049 & 0.028 & $\mathbf{0 . 5 0 7}$ & \\
5. Shopping enjoyment & 0.083 & 0.194 & 0.002 & 0.041 & $\mathbf{0 . 6 6 8}$ \\
Mean & 3.77 & 3.57 & 3.95 & 3.49 & 3.13 \\
SD & 1.28 & 1.06 & 0.88 & 0.82 & $\mathbf{1 . 1 5}$
\end{tabular}

Notes: Values on the diagonal represent the AVE. Squared correlations are shown

Table A2.

Discriminant validity, means and standard deviations

\section{Corresponding author}

Zaira Camoiras-Rodriguez can be contacted at: zaira.camoiras@usc.es

For instructions on how to order reprints of this article, please visit our website: www.emeraldgrouppublishing.com/licensing/reprints.htm Or contact us for further details: permissions@emeraldinsight.com 